\title{
Oral Health for Patients with Special Needs: Evaluative Research of the Dental Specialties Centers
}

\author{
Victor Pinheiro Gavina ${ }^{a} \quad$ Nayara Silva Alves ${ }^{b} \quad$ Francielle Ribeiro Alves $^{a}$ \\ Karine Laura Cortellazzic Flávia Maia Silveira ${ }^{a} \quad$ Andréa Videira Assaf ${ }^{a}$ \\ ${ }^{a}$ Department of Specific Formation, Universidade Federal Fluminense (UFF), Nova Friburgo, Brazil; ${ }^{b}$ Department of \\ Specific Formation, Universidade Vale do Rio Doce (UNIVALE), Governador Valadares, Brazil; ' ${ }^{C}$ Department of Social \\ Dentistry, Piracicaba Dental School, University of Campinas (FOP-UNICAMP), Piracicaba, Brazil
}

\section{Keywords}

Patient satisfaction - Quality of health care · Disabled persons · Oral health · Unified health system · Humanization of assistance

\section{Abstract \\ The Dental Specialties Centers (CEOs) were created within the context of the National Oral Health Policy, and the main function of these establishments is to serve as units of refer- ence in secondary oral health care in the Brazilian national health system (SUS), and they must offer at least the services of stomatology, specialized periodontology, minor oral sur- gery, endodontics, and attendance to patients with special needs. The aim of this study was to evaluate the quality of the CEOs in the mountain region of the Rio de Janeiro State, Brazil, in the perspective of the patients with special needs care or their companion's satisfaction. Data were collected from 159 users by using a standardized self-applied individ- ual semi-structured questionnaire. The results indicated a positive evaluation in most of the dimensions, except the accessibility dimension. Significant differences $(p<0.05)$ were observed between the services of the following dimen- sions of quality: accessibility, resoluteness, technical-scien-}

tific quality, efficiency, efficacy, and acceptability. The analysis of qualitative data, through the discourse of the collective subject technique (DCS) and social representations, showed five central ideas about users' satisfaction and dissatisfaction with CEOs services (humanized health care, resoluteness of the service, professional competence, infrastructure and organization of the service, access to the services). In conclusion, most patients with special needs care and their companions were satisfied with specialized dental centers (SDC) services, although there were significant differences among SDCs services in relation to individuals' satisfaction.

(c) 2018 The Author(s). Published by S. Karger AG, Basel on behalf of NOVA National School of Public Health

\section{Saúde bucal para pacientes com necessidades especiais: pesquisa avaliativa de Centros de Especialidades Odontológicas}

\section{Palavras Chave}

Satisfação do paciente · Qualidade da assistência à Saúde · Pessoas com deficiência · Saúde bucal · Sistema Único de Saúde · Humanização da assistência

\section{KARGER}

E-Mail karger@karger.com www.karger.com/pjp

Karger Open access (c) 2018 The Author(s). Published by S. Karger AG, Basel on behalf of NOVA National School of Public Health

This article is licensed under the Creative Commons AttributionNonCommercial-NoDerivatives 4.0 International License (CC BYNC-ND) (http://www.karger.com/Services/OpenAccessLicense) Usage and distribution for commercial purposes as well as any distribution of modified material requires written permission.
Victor Pinheiro Gavina

Department of Specific Formation, Universidade Federal Fluminense (UFF) Rua Doutor Silvio Henrique Braune, 22 - Centro

Nova Friburgo, RJ 28625-650 (Brazil)

E-Mail victorgavinauff@ hotmail.com 


\section{Resumo}

Os Centros de Especialidades Odontológicas (CEOs) foram criados dentro do contexto da Política Nacional de Saúde Bucal e a principal função desses estabelecimentos é servir como unidades de referência em atenção secundária à saúde bucal no SUS, devendo oferecer pelo menos os serviços de estomatologia, periodontia especializada, cirurgia oral menor, endodontia e atendimento a pacientes com necessidades especiais. O objetivo deste estudo foi avaliar a qualidade dos Centros de Especialidades Odontológicas da região serrana do Estado do Rio de Janeiro, Brasil, por meio da satisfação dos pacientes com necessidades especiais ou de seus acompanhantes. Os dados foram coletados de 159 usuários utilizando um questionário semiestruturado individual auto-aplicado padronizado. Os resultados indicaram uma avaliação positiva na maioria das dimensões, exceto na acessibilidade. Diferenças significativas $(p<0.05)$ foram observadas entre os serviços nas seguintes dimensões de qualidade: acessibilidade, resolutividade, qualidade técnico-científica, eficiência, eficácia e aceitabilidade. A análise dos dados qualitativos, por meio da técnica do Discurso do Sujeito Coletivo (DSC) e das representações sociais, apresentou cinco ideias centrais sobre a satisfação e insatisfação dos usuários com os serviços dos CEOs (cuidado humanizado, resolutividade do serviço, competência profissional, infraestrutura e organização do serviço, acesso aos serviços). Em conclusão, a maioria dos pacientes com necessidades especiais e seus acompanhantes estavam satisfeitos com os serviços dos CEOs, embora houvesse diferenças significativas entre os serviços dos CEOs em relação à satisfação dos indivíduos.

(c) 2018 The Author(s). Published by S. Karger AG, Basel on behalf of NOVA National School of Public Health

\section{Introduction}

In dentistry, patients with special needs are classified as all individuals who present physical, sensory, mental, growth, or medical limitations, whether they are transitory or permanent, and who therefore need differentiated dental treatment. This concept is broad in scope, considering the amplitude of cases that may fit into this definition [1].

According to data published by the World Health Organization (WHO), there are approximately 600 million persons with disabilities in the world; that is, 1 in every 10 persons [2]. In Brazil, according to the Demographic Census of 2010, this population consists of approximate- ly 45.6 million persons, which corresponds to approximately $23.9 \%$ of the Brazilian population. In the state of Rio de Janeiro, the population of disabled persons (3.9 million persons) represents approximately $24.4 \%$ of the total population of the state [3]. In spite of this high contingent of the population, estimates have indicated that the health care needs of only $2 \%$ of the disabled population are met [4].

Health care of persons with special needs is a key element for their inclusion in the society, and consequently this inclusion reflects the equity of access to and use of public health services. Equity in the development and execution of public health policies for disabled persons consists of treating the unequal in an equal manner. Therefore, this principle in the implementation of health programs consists of favoring the neediest groups with regard to access to and use of health services, and this must be the guiding objective of public health policies [5].

The National Health Policy for Persons with Disabilities, and the Plan "Viver Sem Limites" (Live without Limits) proposed the insertion of patients with special needs across the different Ministry of Health programs, and the creation of a Network of Care for Persons with Disabilities within the scope of the Brazilian national health system (SUS). Furthermore, this policy foresees an articulation with the national coordination of oral health so that dental care for patients with special needs will be performed in the "Smiling Brazil" program in a special outpatient system, or in cases of greater need, in a hospital system [6]. The WHO Convention about the Rights of Persons with Disabilities also guarantees the right to access to and use of goods and services in health to disabled persons, without there being any type of discrimination [7].

The Dental Specialties Centers (CEOs) were created within the context of the National Oral Health Policy, and the criteria, standards, and requisites for its implementation and accreditation were instituted by means of Administrative Ruling No. 599/GM. The main function of these establishments is to serve as units of reference in secondary oral health care in SUS, and they must offer at least the services of stomatology, specialized periodontology, minor oral surgery, endodontics, and attendance to patients with special needs [8]. Within this perspective of a larger offer of health services to patients with special needs, financial incentives of contribution to costs were created for CEOs that adhered to the Network of Care for Persons with Disabilities by means of Administrative Ruling No. 835/GM. Therefore, it is mandatory for a CEO that adheres to this network to offer attendance to dis-
82

Port J Public Health 2018;36:81-94 DOI: $10.1159 / 000493886$
Gavina/Alves/Alves/Cortellazzi/Silveira/ Assaf 


\begin{tabular}{|c|c|c|c|c|c|c|c|}
\hline Municipality & CEO & Type of CEO & $\begin{array}{l}\text { Adhered to } \\
\text { NCPD }\end{array}$ & $\begin{array}{l}\text { Dentists for } \\
\text { PSN, } n\end{array}$ & $\begin{array}{l}\text { Population } \\
\text { (inhabitants), } n\end{array}$ & $\mathrm{HDI}$ & $\begin{array}{l}\text { Territorial } \\
\text { extension, } \mathrm{km}^{2}\end{array}$ \\
\hline \multirow[t]{2}{*}{ Petrópolis } & $\begin{array}{l}\text { Dr. Domingos Padula } \\
\text { Primo }\end{array}$ & $\|$ & Yes & 2 & 295,917 & 0.745 & 795,794 \\
\hline & $\begin{array}{l}\text { Pastor Edelto Barreto } \\
\text { Antunes }\end{array}$ & $\|$ & Yes & 1 & & & \\
\hline $\begin{array}{l}\text { Cachoeiras de } \\
\text { Macacu }\end{array}$ & $\begin{array}{l}\text { Ambulatório Padre } \\
\text { Batalha }\end{array}$ & II & Yes & 1 & 54,273 & 0.700 & 953,801 \\
\hline Bom Jardim & $\begin{array}{l}\text { Centro de Saúde José } \\
\text { Alberto Erthal }\end{array}$ & 1 & No & 1 & 25,333 & 0.660 & 384,639 \\
\hline
\end{tabular}

Fig. 1. Sociodemographic characterization of municipalities in the mountainous (serrana) region of the State of Rio de Janeiro and their respective Dental Specialties Centers (CEO). NCPD, Network of Care for Persons with Disabilities; PSN, patients with special needs; HDI, Human Development Index.

abled persons consisting of at least $40 \mathrm{~h}$ per week, in a dental chair exclusively for this type of attendance [9].

Evaluation is a fundamental step when the quality of health services is to be attained, and an instrument is essential for planning, management, and reorientation of public health policies and allocation of resources, which could generate the necessary transformation for improving and enhancing these services $[10,11]$.

According to the present perspectives, evaluation of quality must also be based on the users' satisfaction [12], thus constituting a fundamental quality indicator [10], because it allows the dentist-patient relationship and humanization of dental attendance to be analyzed, and to evaluate factors such as access, waiting time, infrastructure, organization, patient satisfaction with treatment performed and service provided $[10,13,14]$. In addition, it could collaborate with the proposals for enhancing the quality of the service [12].

In the search for a validated quantitative instrument for evaluating the oral health services, the "Questionário de Avaliação dos Serviços de Saúde Bucal (QASSaB)" (Oral health service evaluation questionnaire) was created based on the Donabedian [15] model of quality evaluation that at present comprises seven new dimensions of quality: efficacy, effectiveness, efficiency, optimization, acceptability, legitimacy, and equity [16]. However, user satisfaction is a complex phenomenon, and the use of quantitative instruments only is inadequate to measure it. The use of quantitative instruments based on open questions about experiences and personal opinions of persons interviewed may be an efficient alternative for this type of evaluation [17].

Oral Health for Patients with Special Needs: Evaluative Research of CEOs
In view of the foregoing, the aim of this study was to evaluate the CEOs of the mountain (serrano) region of the State of Rio de Janeiro, by means of the satisfaction of users with special needs and the persons who accompany them with the services provided in these establishments.

\section{Methodology}

Characterization of the Municipalities and Their Respective Services

The present study is of the descriptive, cross-sectional type with exploratory and evaluative characteristics of a qualitative and quantitative nature. The study was developed in the CEOs belonging to the municipalities that adhered to the intermunicipal health consortium of the mountainous (serrano) region of the State of Rio de Janeiro (CIS-Serra).

The municipalities of the State of Rio de Janeiro that adhered to the CIS-Serra up to February 2016 were: Bom Jardim; Cachoeiras de Macacu; Cantagalo; Carmo; Cordeiro; Duas Barras; Guapimirim; Macuco; Nova Friburgo; Petrópolis; Santa Maria Madalena; São José do Vale do Rio Preto; Sumidouro; and Trajano de Moraes.

Among the municipalities belonging to this consortium, only Petrópolis, Bom Jardim, Cachoeiras de Macacu, and São José do Vale do Rio Preto have the installation of a secondary care service in their oral health care network, represented by the CEOs. However, in the period during which this study was conducted, the municipality of São José do Vale do Rio Preto did not offer the specialty of attendance to patients with special needs, and therefore, the authors opted not to include the CEO of this municipality in the study. The sociodemographic characteristics of the municipalities and their respective CEOs are shown in Figure 1.

\section{Sample Selection}

The sample of users with special needs and the persons who accompanied them consisted of 159 individuals, and this population was distributed as follows: CEO A $(n=63)$, CEO B $(n=41)$, 
Humanized health care (positive) - 44\% of the total of key expressions ( $n=99)$

"The dentist gave me a lot of support, attention, and affection; he/she is very calm when talking, always talks to me and asks how I am. Without saying he/she makes me feel very secure and calms me; he/she is always interested in my case and makes himself/ herself available, is concerned about my return and about continuity of my treatment. The professionals are polite kind, have good will in attending to us, and are very patient in caring for us. They interact a great deal with the children as well. Here, I feel at ease to talk to people. I don't feel ashamed or afraid of suffering prejudice"

Humanized health care (negative) - 1.3\% of the total of key expressions ( $n=3$ )

"I think that sometimes a little more interest and attention is missing. Once I was attended to by a dentist who was very insensitive towards me and also didn't have much patience"

Resoluteness of the service (positive) $-15.5 \%$ of the total of key expressions ( $n=35$ )

"My teeth were very carious, full of plaque, with that discomfort, bad breath, inflamed gum; then she treated (me), filled all those holes; that tooth that bothered me was extracted. They manage to resolve our problem, extract teeth, do the canal; when one needs an X-ray they do it right away, were also able to conclude dental things, fillings, dentures. Resolved everything I needed. I don't feel anything anymore, stopped the pain and everything. I am chewing better, my esthetics improved and my teeth have no problems. Here, they always attend to my needs, whatever they could do, they did it"

Resoluteness of the service (negative) $-6.2 \%$ of the total of key expressions $(n=14)$

"I thought it took a long time, and they couldn't resolve what had to be resolved. Sometimes, I went back home without having done anything. The one who worked on me never finished the treatment. I only extracted a tooth. The part to make a denture and filling that could improve my chewing, there they did none of this. I also think they could improve and offer other types of treatment so that I would be able to conclude mine"

Professional competence (positive) - 13.3\% of the total of key expressions $(n=30)$

"The doctor is very good, an excellent dentist. The procedures were well done. She did everything correctly and teaches and explains everything as well. They are very competent, they are dedicated to what they do and know what they are doing. I don't suffer at all for having a tooth pulled out by her. The dentists here are specialized and are very qualified. They also work with prevention, treat before it worsens"

Professional competence (negative) - 3.1\% of the total of key expressions $(n=7)$

"The dentist didn't seem to be a person prepared to care for a special (patient). Up to now, they haven't defined what would be best for my treatment. I have been through three dentists, and the three professionals proposed different treatments for me and did not enter into consensus. The only thing I didn't like was that he didn't explain what would be done and also the fillings are falling out after 3 months. Another thing I didn't like was that the dentist wanted to extract a tooth that could have undergone canal treatment" Resoluteness of the service (positive) $-5.8 \%$ of the total of key expressions $(n=13)$

"The treatment is with hygiene. Here, they have things they don't have in other services. Here, they have all the materials and the brands of things are good. They inform when they are going to miss a consultation and in the majority of times they attend at the right time. Here, they always referred me to a special dentist. My son never had a treatment like he had here. where they have all the appliances to sedate him and have the correct professional for his case"

Infrastructure and organization of the service (negative) - 5\% of the total of key expressions ( $n=11)$

"The dentist only works once a week, and his agenda gets very full. I also think they could inform about the day when he doesn't come. Because they have made me come here for attendance. And have not attended to me. I think they could have more resources and offer other types of more complex treatments. The material is also of poor quality"

Access to the service (positive) $-4.4 \%$ of the total of key expressions $(n=10)$

"I was unable to get attendance anywhere. Either in a private dental office or public; here was the only place I managed to get attendance. I phone and whenever they have a vacancy they attend to me. There is a girl who makes new appointments easily"

Access to the service (negative) - 1.3\% of the total of key expressions ( $n=3$ )

"The waiting time to get treatment is very long, and it takes a long time to achieve things. It is very difficult to take her there as well"

Fig. 2. Central ideas with their total key expressions and respective discourses of the collective subject. 
CEO C $(n=32)$, and CEO D $(n=23)$. The sample was selected from among individuals with special needs who consulted the CEOs in the period of 2 months; and the total period in which the study was conducted was 8 months (July 2015 to February 2016), i.e. 2 months for each health establishment.

The inclusion criteria of this study were: all the users with special needs, who were submitted to a dental procedure (dental treatment) at least once, and who accepted to participate in the study. Individuals with any type of special needs were interviewed, with the exception of those with intellectual/cognitive disability, or those under 18 years of age. In this case, these individuals were included in the study, with the participation of the respective persons who accompanied them/guardians on the day of consultation. The exclusion criteria were: all the individuals who refused to sign the Term of Free and Informed Consent, or Term of Free and Informed Assent; individuals who refused to participate in the research; and individuals who did not fulfill the inclusion criteria.

Thus, in 60 interviews, the patients themselves responded to the questionnaire, and in the 99 remaining interviews, the persons who accompanied them/guardians responded to the same questionnaire due to the criteria previously established for participation in the study.

\section{Pilot Study and Interviewer Training}

The pilot study was conducted to evaluate the level of understanding of the questions by the interviewees $(n=10)$ and make the possible changes in the semi-structured questionnaire.

Training consisted of preparing the interviewer for applying the questionnaire. This preparation was made by a researcher with previous experience in this type of research, by means of conducting some interviews $(n=10)$ with a duration of $8 \mathrm{~h}$.

\section{Qualitative and Quantitative Measurement Instrument}

Data were collected by one previously trained researcher, in reserved rooms at the respective CEOs, preserving the privacy of the interviewees. The instrument used for this collection consisted of semi-structured questionnaires made up of two parts. The first part consisted of closed questions, with information about the socioeconomic and demographic characteristics of the interviewees, and the integrality of the oral health services. The second part of the questionnaire consisted of open and closed questions, based on the Oral Health Service Evaluation Questionnaire (Aqsa), a validated instrument for assessing services, widely used for evaluating oral health services [15].

In this study, the Aqsa covered the following quality dimensions: (1) Accessibility; (2) Resoluteness; (3) Physical Environment - Cleanliness; (4) Human Relations; (5) Technical-Scientific Quality; (6) Efficiency; (7) Efficacy; (8) Equity; (9) Acceptability.

The qualitative part of this study consisted of evaluation, by means of an open question, with the purpose of verifying the main reasons for satisfaction and dissatisfaction with the services provided by the CEOs ("What is the reason why you are dissatisfied or satisfied with the services provided by the CEO?"). All the interviews were recorded after obtaining authorization from the interviewees. These were later transcribed; however, when the interviewees did not authorize recording, the researcher transcribed the speeches during the course of the interview.

\section{Manner of Analyzing the Results}

The quantitative data were first digitized on an Excel spreadsheet, and afterwards exported to the Program R, version 3.2.5. Initially, a descriptive analysis was made by means of frequency of distribution of the sample among the study variables. Afterwards the $\chi^{2}$ and exact Fisher statistical tests were used, with a level of significance of $5 \%$, to evaluate whether there were any differences in the study variables among the different CEOs.

The content of the qualitative data was analyzed by means of the discourse of the collective subject [18] for interpreting the interviewees' responses, performed by two trained researchers. The researchers read, transcribed, and identified the topics that arose in the data of each interview. The phrases, words, or expressions that referred to satisfaction or dissatisfaction with the services provided by the CEOs were underlined in the transcription. The level of agreement between the examiners during categorization was good $(85.7 \%)$. This was calculated based on the selection of key expressions contained in the interviewees' responses, and their respective classification according to the central ideas (Fig. 2).

\section{Results}

\section{Social Characterization and Types of Special Needs}

With the use of the modified Santos and Haddad classification [19], the results showed that the systemic conditions or diseases and metal deficiency were the most prevalent, with 26.4 and $25.8 \%$ of the total number of individuals interviewed at the CEOs, respectively (Table 1). Sociodemographic characterization of the sample is shown in Table 2, in which significant differences were observed among the CEOs relative to educational level $(p=0.03)$ and family income $(p=0.004)$.

\section{Integrality of the Oral Health Care Network}

As far as this parameter was concerned, a frail system of reference and counter reference was observed, considering that in the total group, approximately $82.5 \%$ of the patients arrived at the CEOs without having been referred or referenced by primary oral health care professionals. There were significant differences between the CEOs in this variable $(p<0.01)$, with CEO D presenting the best results relative to the integrality of the oral health care network (Table 3).

\section{Quantitative Evaluation of Quality Dimension by the \\ Total Group}

The results of the quality dimensions in the total group and per CEO are shown in Table 3.

Positive evaluations were observed in all the variables of the quality dimensions, with the exception of the dimension accessibility, which presented a negative evaluation for the variables "time spent on arriving at the 
Table 1. Classification of patients with special needs cared for in the Dental Specialties Centers (CEOs) (Modified Santos and Haddad Classification)

\begin{tabular}{lccccc}
\hline Special need & CEO 1 & CEO 2 & CEO 3 & CEO 4 & Total \\
\hline Physical disability & $8(12.7)$ & $5(12.2)$ & $5(15.6)$ & $2(8.7)$ & $20(12.5)$ \\
Behavioral & $6(9.5)$ & $4(9.8)$ & $0(0)$ & $0(0)$ & $10(6.3)$ \\
Systemic diseases and conditions & $9(14.3)$ & $15(36.6)$ & $13(40.6)$ & $5(21.7)$ & $42(26.4)$ \\
Mental deficiency & $17(27)$ & $7(17.1)$ & $8(25)$ & $9(39.1)$ & $41(25.8)$ \\
Sensory disturbances & $1(1.6)$ & $0(0)$ & $1(3.1)$ & $0(0)$ & $2(1.2)$ \\
Psychiatric disorders & $4(6.3)$ & $1(2.4)$ & $2(6.2)$ & $3(13)$ & $10(6.3)$ \\
Infectious/contagious diseases & $12(19)$ & $0(0)$ & $0(0)$ & $0(0)$ & $12(7.5)$ \\
Craniofacial syndromes and deformities & $4(6.3)$ & $8(19.5)$ & $3(9.4)$ & $4(17.4)$ & $19(11.9)$ \\
Diagnosis not concluded & $2(3.2)$ & $1(2.4)$ & $0(0)$ & $0(0)$ & $3(1.9)$ \\
\hline Total & $63(100.0)$ & $41(100.0)$ & $32(100.0)$ & $23(100.0)$ & $159(100.0)$ \\
\hline \multicolumn{1}{c}{ Data are presented as $n(\%)}$. & & &
\end{tabular}

CEO," "waiting for attendance," and "interval between consultations." However, this same dimension revealed positive results for the variables "obtaining a vacancy" and "infrastructure for disabled persons," with 66.6 and $52.1 \%$ respectively, of the interviewees providing positive evaluation of the service. The variable "infrastructure for disabled persons" was evaluated positively when the responses "Completely adequate/very adequate" and "Adequate" were totaled.

However, in the dimension "resoluteness," all the variables (appearance of the teeth, chewing, and resolution of the problem) presented positive evaluations in the total group. The variables "appearance of the teeth" and "chewing" demonstrated 70.9 and $58.4 \%$ of favorable responses ("Completely improved/much improved" and "Improved"), respectively.

Regarding the physical environment dimension cleaning, all the variables also showed positive evaluations (very good/good) by the majority of the interviewees. The variables cleaning of the dental offices, bathrooms, reception/waiting room were found to present positive evaluation in $90.6,64.5$, and $88 \%$ of the study participants, respectively.

Within this same trend towards positive evaluation of the service, the authors could find that in the human relations dimension, the variables "attendance provided by the dentist," "attendance provided by the assistant," and "degree of confidence in the dentist" were evaluated as "very good/good" by $96.2,95.5$, and $94.4 \%$ of the individuals participating in this study, respectively.

Generally speaking, the technical-scientific quality dimensions of the equipment, efficiency, efficacy, equity, and acceptability followed this trend towards positive evaluation with, for example, $74.2 \%$ of the patients reporting that they felt no discomfort whatever during the course of the consultation; $68.2 \%$ of the respondents declaring they had their needs equally met in the public and private service; $80.4 \%$ saying that the dentist always, or in the majority of times, explained the proposed treatment; and $53.5 \%$ of the individuals reporting that the CEO team always or in the majority of times asked for their opinion relative to the best day for making the appointment for the consultation, among other variables.

\section{Quantitative Evaluation of the Quality Dimension per Dental Specialty Center}

The comparative results among the CEOs showed that in general, significant differences were found among them with regard to the following dimensions/variables: accessibility/obtaining a vacancy $(p<0.001)$, accessibility/infrastructure for disabled persons $(p=0.03)$, resoluteness/appearance of the teeth $(p=0.001)$, resoluteness/ chewing $(p=0.02)$, resoluteness/resolution of the problem $(p<0.001)$, technical-scientific quality of the items of equipment/equipment $(p=0.002)$, efficiency/cost-benefit $(p<0.001)$, efficacy/discomfort during consultations $(p=0.04)$, and acceptability/explanation of treatment and opinion about the day for making the appointment $(p<$ 0.001 ). In general, CEO B presented the worst evaluation in the variable infrastructure for disabled persons of the dimension accessibility. CEO C presented the worst results in the dimensions/variables: accessibility/obtaining a vacancy; resoluteness/appearance of the teeth and chewing; technical-scientific dimension/dental office equip-
Gavina/Alves/Alves/Cortellazzi/Silveira/ Assaf 
Table 2. Characterization of a sample of 159 users attended to at the Dental Specialty Centers (CEOs) in the mountainous (serrana) region of the State of Rio de Janeiro, Brazil, 2016

\begin{tabular}{|c|c|c|c|c|c|c|c|c|c|c|c|}
\hline Variable & \multicolumn{2}{|c|}{ CEO A } & \multicolumn{2}{|c|}{ CEO B } & \multicolumn{2}{|c|}{ CEO C } & \multicolumn{2}{|c|}{ CEO D } & $p$ value $^{\mathrm{a}}$ & \multicolumn{2}{|c|}{ Total group } \\
\hline$\leq 35$ years & 35 & 55.6 & 17 & 41.5 & 14 & 43.7 & 13 & 56.5 & $0.52^{\mathrm{c}}$ & 79 & 50.3 \\
\hline$>35$ years & 28 & 44.4 & 24 & 58.5 & 18 & 56.3 & 10 & 43.5 & & 80 & 49.7 \\
\hline Female & 22 & 34.9 & 16 & 39.0 & 16 & 50.0 & 14 & 60.9 & & 68 & 42.8 \\
\hline \multicolumn{12}{|l|}{ Marital status } \\
\hline Married & 23 & 36.5 & 16 & 39.0 & 16 & 50.0 & 13 & 56.5 & $0.59^{\mathrm{b}}$ & 68 & 42.9 \\
\hline Single & 21 & 33.3 & 14 & 34.1 & 9 & 28.1 & 4 & 17.4 & & 48 & 30.2 \\
\hline Widowed & 8 & 12.7 & 5 & 12.2 & 3 & 9.4 & 5 & 21.7 & & 21 & 13.1 \\
\hline Mulatto & 18 & 28.6 & 16 & 39.0 & 13 & 40.6 & 8 & 34.8 & & 55 & 34.6 \\
\hline Yellow & - & - & - & - & - & - & - & - & & - & - \\
\hline Indigenous & - & - & - & - & - & - & - & - & & - & - \\
\hline \multicolumn{12}{|l|}{ Educational level } \\
\hline Illiterate & 1 & 1.6 & 3 & 7.3 & 3 & 17.4 & 4 & 17.4 & $0.03^{b}$ & 11 & 6.9 \\
\hline PS incomplete & 29 & 46.0 & 21 & 51.2 & 18 & 52.2 & 12 & 52.2 & & 80 & 50.2 \\
\hline PS complete & 14 & 22.2 & 2 & 4.9 & 0 & 13.0 & 3 & 13.0 & & 19 & 12.0 \\
\hline HS incomplete & 2 & 3.2 & 4 & 9.8 & 4 & 4.3 & 1 & 4.3 & & 11 & 6.9 \\
\hline HS complete & 11 & 17.5 & 6 & 14.6 & 6 & 8.7 & 2 & 8.7 & & 25 & 15.8 \\
\hline College incomplete & 4 & 6.3 & 1 & 2.4 & 0 & 4.3 & 1 & 4.3 & & 6 & 3.7 \\
\hline College complete & 2 & 3.2 & 4 & 9.8 & 1 & 0.0 & 0 & 0.0 & & 7 & 4.4 \\
\hline$>5$ & 4 & 6.3 & 1 & 2.4 & 1 & 3.1 & 0 & 0.0 & & 6 & 3.7 \\
\hline Total & 63 & 100.0 & 41 & 100.0 & 32 & 100.0 & 23 & 100.0 & & 159 & 100.0 \\
\hline
\end{tabular}

${ }^{a}$ Comparison of the distribution of variables among the dental specialty centers. ${ }^{b}$ Fisher exact test. ${ }^{c}$ Pearson $\chi^{2}$ test.

ment, and acceptability/opinion about making the appointment for consultation. In CEO D, the authors observed the worst performance of user satisfaction in the following dimensions/variable: resoluteness/appearance of the teeth and chewing; resoluteness/resolution of the problem; technical-scientific dimension/dental office equipment; efficiency/cost-benefit; efficacy/discomfort during consultations; acceptability/explanation of treat- ment and opinion about making the appointment for consultation.

\section{Qualitative Evaluation of the CEOs by the Total Group}

After analysis and interpretation of the qualitative data, the central ideas that arose for expressing satisfaction or dissatisfaction with the services provided by the 
Table 3. Individualized evaluation of satisfaction of users of Dental Specialty Centers (CEO) in the mountainous (serrana) region of the State of Rio de Janeiro, Brazil, 2016

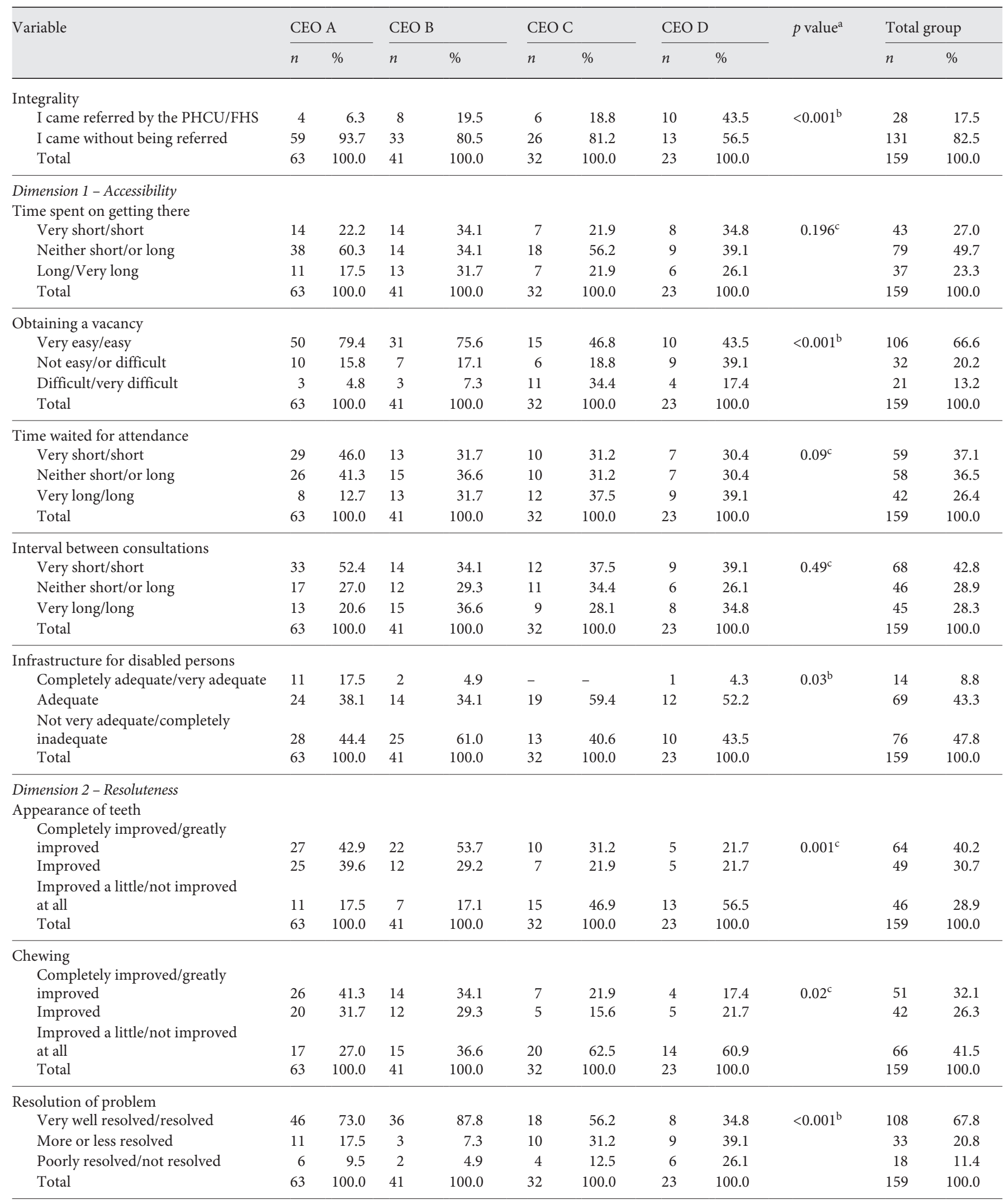


Table 3 (continued)

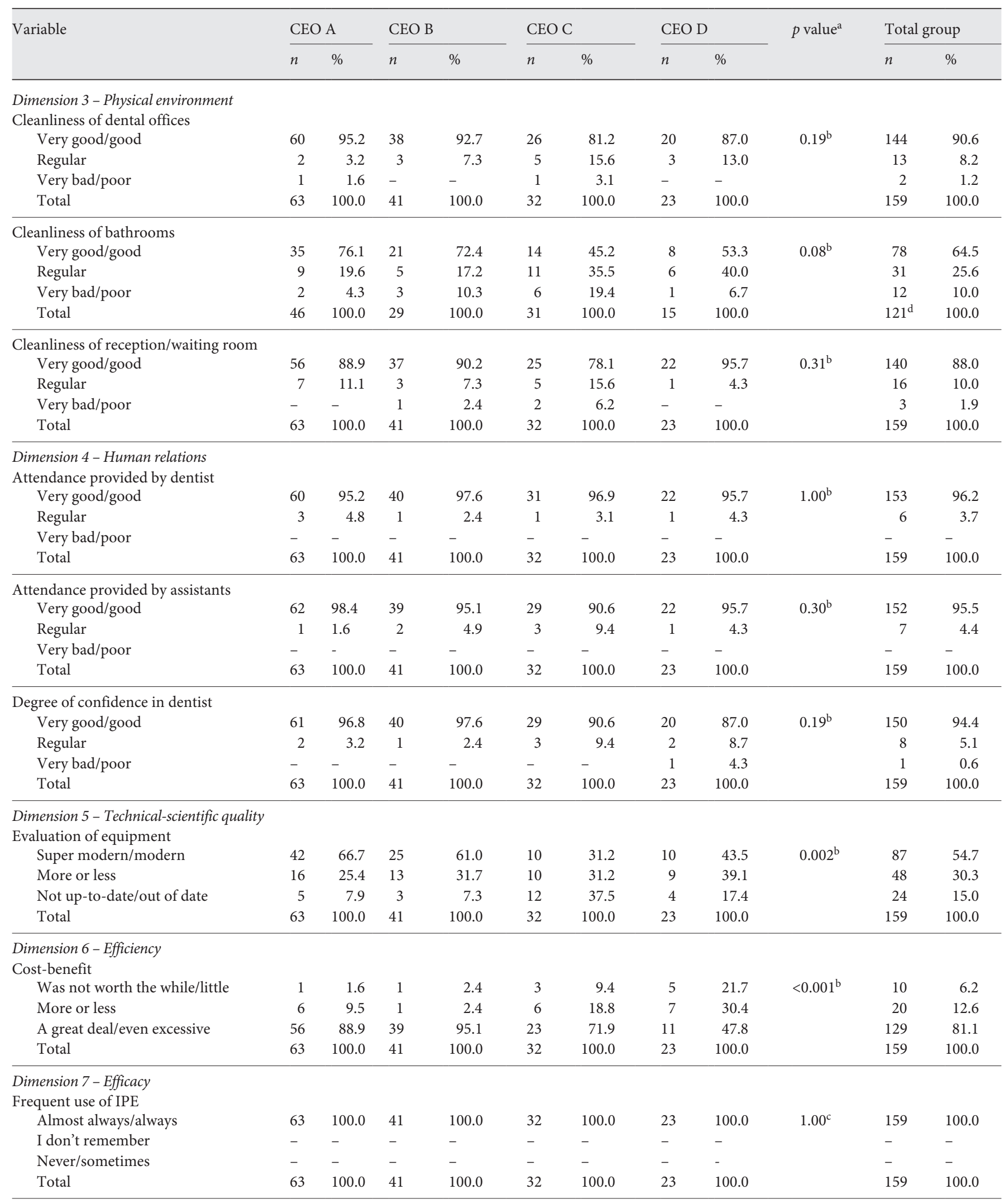


Table 3 (continued)

\begin{tabular}{|c|c|c|c|c|c|c|c|c|c|c|c|}
\hline Variable & \multicolumn{2}{|c|}{ CEO A } & \multicolumn{2}{|c|}{ CEO B } & \multicolumn{2}{|c|}{ CEO C } & \multicolumn{2}{|c|}{ CEO D } & $p$ value $^{\mathrm{a}}$ & \multicolumn{2}{|c|}{ Total group } \\
\hline I didn't feel anything & 49 & 77.8 & 31 & 75.6 & 27 & 84.4 & 11 & 47.8 & $0.04^{\mathrm{b}}$ & 118 & 74.2 \\
\hline Little discomfort/discomfort & 12 & 19.0 & 8 & 19.5 & 4 & 12.5 & 7 & 30.4 & & 31 & 19.4 \\
\hline $\begin{array}{l}\text { Much discomfort/complete } \\
\text { discomfort }\end{array}$ & 2 & 3.2 & 2 & 4.9 & 1 & 3.1 & 5 & 21.7 & & 10 & 6.3 \\
\hline \multicolumn{12}{|l|}{ Dimension 8 - Equity } \\
\hline \multicolumn{12}{|l|}{ Public versus private } \\
\hline Are not attended & 1 & 1.7 & 1 & 2.6 & 2 & 6.2 & 2 & 9.5 & $0.14^{\mathrm{b}}$ & 6 & 4.0 \\
\hline $\begin{array}{l}\text { Partially attended/attended } \\
\text { differently }\end{array}$ & 14 & 23.3 & 8 & 21.1 & 11 & 34.4 & 9 & 42.9 & & 42 & 27.9 \\
\hline Equally attended & 45 & 75 & 29 & 76.3 & 19 & 59.4 & 10 & 47.6 & & 103 & 68.2 \\
\hline Always/the majority of times & 60 & 95.2 & 36 & 87.8 & 22 & 68.8 & 10 & 43.5 & $<0.001^{\mathrm{b}}$ & 128 & 80.4 \\
\hline I don't remember & - & - & - & - & 1 & 3.1 & - & - & & 1 & 0.6 \\
\hline Rarely/never & 3 & 4.8 & 5 & 12.2 & 9 & 28.1 & 13 & 56.5 & & 30 & 18.9 \\
\hline Total & 63 & 100.0 & 41 & 100.0 & 32 & 100.0 & 23 & 100.0 & & 159 & 100.0 \\
\hline \multicolumn{12}{|l|}{ Opinion on day of appointment } \\
\hline Never ask/rarely ask & 29 & 46.0 & 7 & 17.1 & 21 & 65.6 & 17 & 73.9 & $<0.001^{\mathrm{c}}$ & 74 & 46.5 \\
\hline I don't remember & - & - & - & - & - & - & - & - & & - & - \\
\hline The majority of times/always ask & 34 & 54.0 & 34 & 82.9 & 11 & 34.4 & 6 & 26.1 & & 85 & 53.5 \\
\hline Total & 63 & 100.0 & 41 & 100.0 & 32 & 100.0 & 23 & 100.0 & & 159 & 100.0 \\
\hline
\end{tabular}

${ }^{a}$ Comparison of the distribution of variables among the dental specialty centers. ${ }^{b}$ Fisher exact test. ${ }^{c}$ Pearson $\chi^{2}$ test. ${ }^{\mathrm{d}} 38$ respondents reported never having used the bathroom of the $\mathrm{CEO}$, and 8 respondents said they had never been to a private dentist.

CEOs were the following: humanized health care; resoluteness of the service; competence of the professionals; infrastructure and organization of the service; and access to the service (Fig. 2). Transcription of the 159 interviews presented a total of 225 key expressions containing positive $(83.6 \%)$ or negative $(16.4 \%)$ connotations, and that fitted in with the central ideas of evaluation of the services.

The central ideas most frequently mentioned by the respondents to express their satisfaction with the services were the following: humanized health care ( $44 \%$ of the responses), followed by resoluteness of the services ( $16 \%$ of the responses). The most frequent central ideas for expressing dissatisfaction with the services were the following: resoluteness (5.8\% of the responses), followed by infrastructure and organization of the services (5\% of the responses).

\section{Qualitative Evaluation per CEO}

Analysis of the results per establishment showed that in all the CEOs the most frequent central ideas for users' satisfaction were humanized health care and resoluteness of the services. This trend was not observed only in CEO $\mathrm{C}$ because the most frequent central ideas in this establishment were humanized health care and competence of the professionals.

In CEOs $\mathrm{A}$ and $\mathrm{B}$, the authors also observed that all the central ideas presented a higher percentage of positive than negative evaluations, differently from CEOs $\mathrm{C}$ and D. In CEO C, the negative evaluations exceeded the positive in the central ideas of infrastructure and organization of the services, and access to the services. In CEO D, the central ideas competence of the professionals and infrastructure, and organization of the services also presented more negative than positive evaluations. The DCS of each central idea is shown in Figure 2.
90
Port J Public Health 2018;36:81-94 DOI: $10.1159 / 000493886$
Gavina/Alves/Alves/Cortellazzi/Silveira/ Assaf 
The authors found that the qualitative results corroborated the quantitative results of this study.

\section{Discussion}

From the foregoing results shown, the authors were able to verify that in general, there was a high degree of satisfaction with the services provided by the CEOs belonging to CIS-Serra among the patients with special needs or the persons who accompanied them.

Relative to the integrality of the system of reference and counter reference of the oral health care network of the studied municipalities, frail articulation was observed between primary and secondary care. Possible justifications for this finding may be pointed out as being: lack of knowledge of primary care professionals as regards the Ministry of Health protocols for referral of patients with special needs to secondary care, deficient professional training of the general clinician for attending to this type of patient, and the very lack of information by the users about how the oral health care network functions, seeing that they use the CEO as a port of entry to SUS in the majority of occasions. This fact deserves to be emphasized, seeing that the users' port of entry into SUS should be primary care, in which the individual receives assistance, guidance, and referral to secondary or tertiary care in case of need. This integrality within the health care network allows a rational distribution of the users in the different services, thereby avoiding overload at any level of care by SUS [20]. However, the study of Casotti et al. [21]. revealed the existence of reference and counter reference protocols for referring patients to the CEOs in approximately $62.7 \%$ of the oral health teams in the southeastern regions, which counted on this service in their oral health care network. This could suggest that these protocols are perhaps not being duly used by the professionals.

Here, the high prevalence of patients with systemic conditions and diseases being cared for by the CEOs should also be emphasized. Although this group of patients present the need for special care, they should preferably be attended to in primary care, and only when necessary, must they be referred to the CEO with a professional report from primary care, justifying this referral. Moreover, the list of basic procedures for the care of patients with special needs stated in Administrative Ruling 1464/GM of 2011 is destined exclusively for those patients who do not cooperate with having treatment performed and those who are severely compromised. It is mandatory for these patients to be attended to by a specialist [1].

In the quality dimensions evaluated, accessibility was the variable that presented the worst results in the total group of this study. This quality dimension is extremely important, seeing that the factor that most influences the satisfaction of users with the services is adequate access to these services [22]. The variable "time spent to arrive at the CEO" presented negative results; however, this finding was expected, and could not be considered bad, because, considering that the CEOs are centers of reference, they must not necessarily be close to the population's residences. Their geographical localization must take into account only the question of economy of scale. Obtaining a vacancy for attendance consists of one of the main means for the user to have adequate access and first contact with the health services, and this must be considered in the organization and evaluation of these services [23]. The time spent waiting for attendance was also one of the obstacles found by users and was reported in the study of Franco and Campos [11]. In this sense, this aspect deserves special attention, considering that the population of this study consisted of patients with special needs who, in some cases, had different needs (food, hygiene) in comparison with the general population [24]. Another factor to be pointed out for better integration into and access to health services by the population under study is the existence of infrastructure of these establishments with conditions of safety and use, in addition to complete independence by persons with disabilities or reduced mobility. Law decree No. 5.296/2004, which regulates Laws No. $10.048 / 2000$ and $10.098 / 2000$, guarantees priority attendance to persons with disability or reduced mobility in public offices and institutes general rules and basic criteria for the promotion of accessibility to these establishments by these individuals [25]. The infrastructure geared for the attendance to disabled persons in the CEOs was considered satisfactory by the majority of individuals in this study, with the exception of CEO B. These results corroborated the findings of the study of Machado and Nogueira [26] who revealed the absence of problems related to accessibility by users with disabilities, in relation to the infrastructure of a physical therapy clinic. Thus, all the factors related above deserve to be taken into consideration in the management and organization of the studied CEOs.

The data of this study pointed out a high degree of resoluteness in CEOs A and $\mathrm{B}$, which may be observed in the discourse with reference to the central ideas, with the second most mentioned being in relation to satisfaction, 
and the first in relation to dissatisfaction with the services, which is in agreement with the quantitative results of the studies of Lima et al. [27] and Magalhães et al. [28].

The human relations between professionals and users of the CEOs were also reasons for satisfaction by the participants of this research, both quantitatively and qualitatively, as was the case in other studies using the same instruments of evaluation [27-29]. The basis for patient satisfaction consists of the manner in which the user is treated in the health services. Cold, dehumanized relations distance patients from professionals and make it difficult for them to adhere to treatment. The establishment of ties between professionals and patients and their families presupposes the development of harmonious and humanized relations between the two parties, as well as the appreciation of the subjective being, taking into consideration psychosocial aspects in their treatment, and not only traditional scientific knowledge based only on the biological dimension of the health-disease process. These findings were clearly shown in the study, seeing that approximately $44 \%$ of the key expressions contained in the discourses for expressing satisfaction of the interviewees with the service were related to the central idea of "humanized health care." This same trend was strongly observed in the quantitative part of the study, in which the evaluation of the dimension/variable "human relations/attention provided by the dentist" was positively evaluated by $96.2 \%$ of the users/and those who accompanied them. This being so, the human dimension of treatment must be appreciated as much as the technical dimension $[14,30]$.

Relative to the dimension efficiency, the authors observed a high percentage of individuals judging that it was worthwhile to seek the CEO to have their dental treatment performed, or that of the persons who accompanied them. According to Magalhães et al. [28], these data may be explained by the fact that the secondary care services offer more complex, expensive treatments to which a large part of the population find difficulty in gaining access.

Another dimension that deserved emphasis in this study was that of equity. This showed that the majority of individuals considered that their needs were met equally when the public service (CEO) was compared with private service. This is extremely positive, seeing that the Brazilian media frequently tries to propagate the idea that the public health services present a worse level of quality than the private services [31].

The present study demonstrated the importance of professional interaction with users, taking into consider- ation their needs and choices, placing value on their independence in health care and exchange of knowledge between the social actors involved in this process [32]. This finding could be proved in the findings of the dimension accessibility, in which the majority of the individuals interviewed reported that the dentist always, or the majority of the times explained the proposed treatment, and the question about what the best day and time were for making the appointment for consultations. This quality dimension has a concept that is broad in scope, requiring greater depth of the instruments for evaluating it.

The authors also found greater satisfaction of the users with special needs in the CEOs that adhered to the Network of Care for Persons with Disabilities (NCPD), which could be related to a more mature and organized management of these municipalities, and that for this reason, they seek state and federal resources to promote improvement in the offer of their services. These findings reinforce the need for greater stimulus on the part of the State Government and State and Regional Bipartite Interactive Committees to realize the regionalization of secondary oral health care and adhesion to public health policies for persons with disabilities in the municipalities belonging to CIS-Serra [33, 34].

The present study had some possible inherent limitations regarding the evaluation of quality of public health services through users' perception. The level of satisfaction was high in the large portion of the CEOs, and some factors may have influenced these results. Among these are the reluctance of users to suffer reprisals due to a negative evaluation of the service [35] and gratitude (gratitude bias) $[36,37]$ for the attendance received and access to the services, seeing that the population of patients with special needs have difficulty in gaining access to the services, for either socioeconomic, geographic, or organizational reasons [24]. This difficult access makes it impossible for individuals to have their dental needs adequately met.

However, the positive points may also be considered, seeing that this study was probably the first to evaluate the services of secondary care in relation to the attendance to patients with special needs in Brazil; and the first study to evaluate quality through the perception of users in the Dental Specialty Centers in the mountainous (serrano) region of the State of Rio de Janeiro, Brazil. Moreover, the dropout of participants from the study was very small; therefore, the sample was representative.

Lastly, the authors point out the relevance of this study for understanding the dimensions of the quality of Brazilian dental services in secondary care from the perception 
of users with special needs. The incentive provided by this evaluation to the managers and health teams for improvement and enhancement of their services is a trend followed by one of the main national programs to evaluate the quality of public health services (PMAQ-CEO) [38].

\section{Final Considerations}

The CEOs of the mountainous (serrano) region of the State of Rio de Janeiro are services that present particularities and differences when they are evaluated individually.

The results of this research emphasized the importance of human relations between professionals and patients in the quality of health care of individuals with special needs, seeing this as one of the main reasons for the satisfaction of these users.

In view of this, it is possible to conclude that there is a constant need for managers and health teams to perform quality evaluation of their services from the users' perception, thus enabling social participation in SUS, a principle recommended by Brazilian sanitary reform.

\section{Statement of Ethics}

This research was approved by the Research Ethics Committee of the "Universidad Federal Fluminense" - Nova Friburgo complex, and obtained a report favorable to conducting the study, by means of Protocol CAEE No. 51509015.2.0000.5626, and was in compliance with Resolution $466 / 12$ of the National Health Council.

\section{Disclosure Statement}

The authors declare that there are no known conflicts of interest associated with the publication of this manuscript and there has been no significant financial support for this work that could have influenced its outcome. Indeed, the authors declare that this research was developed with own financial resources.

\section{References}

1 Brasil. Ministério da Saúde. Secretaria de Atenção à Saúde. Departamento de Atenção Básica. Saúde bucal. Brasília: Ministério da Saúde; 2008. (Cadernos de Atenção Básica, 17).

2 World Health Organization. The World Oral Health Report 2003: continuous improvement of oral health in the 21st century: the approach of the WHO Global Oral Health Programme. Geneva: WHO/NMH/NPH/ ORH; 2003.

3 IBGE. Características gerais da população. Censo demográfico 2000. Rio de Janeiro: IBGE; 2003

4 Brasil. Ministério da Saúde. Programa Nacional de Assistência Odontológica Integrada ao Paciente Especial. Brasília: Ministério da Saúde, SNAS; 1992.

5 Carneiro N Junior, Silveira C. Organização das práticas de atenção primária em saúde no contexto dos processos de exclusão/inclusão social. Cad Saude Publica. 2003;19(6):1827-35.

6 Chagas AM. Avanços e impedimentos para a construção de uma política social para pessoas com deficiência [dissertação de mestrado]Brasília: Universidade de Brasília; 2006.

7 Decreto Legislativo ${ }^{\circ} 186$, de 09 de julho de 2008: Decreto $\mathrm{n}^{\circ} 6.949$, de 25 de agosto de 2009. Brasil. Convenção sobre os Direitos das Pessoas com Deficiência: Protocolo Facultativo à Convenção sobre os Direitos das Pessoas com Deficiência: $4^{\text {a }}$ ed., rev. e atual. Brasília: Secretaria de Direitos Humanos; 2010.
8 Portaria $n^{\circ}$. 599. Ministério da Saúde. Define a implantação de especialidades odontológicas (CEO) e de laboratórios regionais de próteses dentárias (LRPDs) e estabelece critérios, normas e requisitos para seu credenciamento. Diário Oficial da União. 2006; 24 março.

9 Portaria no ${ }^{\circ}$ 835. Ministério da Saúde. Institui incentivos financeiros de investimento e de custeio para o componente atenção especializada da rede de cuidados à pessoa com deficiência no âmbito do Sistema Único de Saúde. Diário Oficial da União. 2012; 25 abril.

10 Franco SC, Campos GW. [Access to the pediatric ambulatory service at a university hospital]. Rev Saude Publica. 1998 Aug;32(4):35260.

11 Franco SC, Campos GW. [Quality-of-care assessment in a university hospital pediatric clinic]. Cad Saude Publica. 1998b Apr;14(1): 61-70.

12 Kloetzel K, Bertoni AM, Irazoqui MC, Campos VP, Santos RN. [Quality control in primary health care. I - Consumer satisfaction]. 1998 Jul-Sep;14(3):623-8.

13 Assunção MC, Santos Id, Gigante DP. [Diabetes mellitus at the primary health care level in Southern Brazil: structure, course of action and outcome]. Rev Saude Publica. 2001 Feb; 35(1):88-95.

14 Ramos DD, Lima MA. [Health care access and receptivity to users in a unit in Porto Alegre, Rio Grande do Sul, Brazill. Cad Saude Publica. 2003 Jan-Feb;19(1):27-34.
15 Fernandes LMAG: Validação de um instrumento para avaliação da satisfação dos usuários, com os serviços públicos de saúde bucal [tese de doutorado]. Camaragibe: Faculdade de Odontologia. Universidade de Pernambuco; 2002.

16 Donabedian A. The seven pillars of quality. Arch Pathol Lab Med. 1990 Nov;114(11): 1115-8.

17 Edwards C, Staniszewska S. Accessing the user's perspective. Health Soc Care Community. 2000 Nov;8(6):417-24.

18 Lefèvre F, Lefèvre AM, Teixeira JJ. O discurso do sujeito coletivo: uma nova abordagem metodológica em pesquisa qualitativa. Caxias do Sul: EDUCS; 2000.

19 Santos MT, Haddad AS. Quem são os pacientes com necessidades especiais? In: Cardoso RJ, Machado ME, editors. Odontologia: arte e conhecimento. São Paulo: Artes Médicas; 2003. pp. 263-8.

20 Pucca JR. Por um Brasil sorridente. Rev ABO Nac. 2004;12:73-9.

21 Casotti E, Contarato PC, Fonseca AB, Borges $\mathrm{PK}$, Baldani MH. Atenção em saúde bucal no Brasil: uma análise a partir da Avaliação Externa do PMAQ-AB. Saúde Debate. 2014;38 special: $140-57$.

22 Bamise C, Bada T, Bamise F, Ogunbodede E. Dental care utilization and satisfaction of residential university students. Libyan J Med. 2008 Sep;3(3):140-3.
Oral Health for Patients with Special Needs: Evaluative Research of CEOs 
23 Frenk J. [Concept and measurement of accessibility]. Salud Publica Mex. 1985 Sep-Oct; 27(5):438-53.

24 Castro SS, Lefèvre F, Lefèvre AM, Cesar CL. Acessibilidade aos serviços de saúde por pessoas com deficiência. Rev Saude Publica. 2011;45(1):99-105.

25 Decreto n $^{\circ} 5.296$ de 02 de dezembro de 2004 Brasil. - DOU de 03/12/2004. Acesso em: 20 out. 2005.

26 Machado NP, Nogueira LT. Avaliação da satisfação dos usuários de serviços de Fisioterapia. Rev Bras Fisioter. 2008;12(5):401-8.

27 Lima AC, Cabral ED, Vasconcelos MM. Satisfação dos usuários assistidos nos Centros de Especialidades Odontológicas do Município do Recife, Pernambuco, Brasil. Cad Saude Publica. 2010 May;26(5):991-1002.

28 Magalhães BG, Oliveira RS, Góes PS, Figueiredo N. Avaliação da qualidade dos serviços prestados pelos Centros de Especialidades Odontológicas: visão dos usuários. Cad Saude Colet. 2015;23(1):76-85.
29 Marcinowicz L, Chlabicz S, Grebowski R. Patient satisfaction with healthcare provided by family doctors: primary dimensions and an attempt at typology. BMC Health Serv Res. 2009 Apr;9(1):63.

30 Backes DS, Koerich MS, Rodrigues AC, Drago LC, Klock P, Erdmann AL. [What do the users think and say about the Brazilian Health System (SUS)? An analysis of meanings based on the users' rights booklet]. Cien Saude Colet. 2009 May-Jun;14(3):903-10.

31 Souza EM. A satisfação dos idosos com os serviços de saúde: um estudo de prevalência e de fatores associados em Taguatinga, Distrito Federal [dissertação de mestrado]Brasília: Faculdade de Ciências da Saúde. Universidade de Brasília; 1997.

32 Pinto BM, Machado CJ, Sá EO. Características necessárias de um profissional de saúde que trabalha com pacientes portadores de necessidades especiais: um contraste de visões de profissionais e alunos de odontologia, pais e cuidadores. Belo Horizonte: Faculdade de Odontologi, Universidade Federal de Minas Gerais; 2004
33 Nicoletto SC, Cordoni L Jr, Costa NR. Consórcios Intermunicipais de Saúde: o caso do Paraná, Brasil. Cad Saude Publica. 2005 JanFeb;21(1):29-38

34 Neves LA, Ribeiro JM. Consórcios de saúde: estudo de caso exitoso. Cad Saude Publica. 2006 Oct;22(10):2207-17.

35 Andrade KL, Ferreira EF. Avaliação da inserção da odontologia no Programa de Saúde da Família de Pompéu/MG: a satisfação do usuário. Cien Saude Colet. 2006;11(1):12330.

36 Traverso-Yépez M, de Morais NA. Consórcios Intermunicipais de Saúde: o caso do Paraná, Brasil. Cad Saude Publica. 2004 JanFeb;20(1):80-8.

37 Vaitsman J, Andrade GR. Satisfação e responsividade: formas de medir a qualidade e a humanização da assistência à saúde. Cien Saude Colet. 2005;10(3):599-613.

38 Portaria $\mathrm{n}^{\circ}$ 1.599. Ministério da Saúde. Dispõe sobre o Programa de melhoria do acesso e qualidade dos centros de especialidades odontológicas (PMAQ-CEO). Diário Oficial da União 2015; 30 set. 